\author{
V. S. BLIKHAR ${ }^{1 *}$, I. M. ZHAROVSKA ${ }^{2 *}$, I. O. LYCHENKO ${ }^{3 *}$ \\ ${ }^{1 *}$ Lviv State University of Internal Affairs (Lviv, Ukraine), e-mail blikharv@ ukr.net, ORCID 0000-0001-7545-9009 \\ ${ }^{2 *}$ Lviv Polytechnic National University (Lviv, Ukraine), e-mail irazhar@ukr.net, ORCID 0000-0003-3821-8120 \\ ${ }^{3 *}$ Lviv Polytechnic National University (Lviv, Ukraine), e-mail lychenko7@ gmail.com, ORCID 0000-0002-4838-3579
}

\title{
SOCIO-CULTURAL AND PHILOSOPHICAL-LEGAL DIMENSIONS OF THE GENDER IDENTITY PROBLEM
}

Purpose. Based on the comparative analysis of the European and post-Soviet countries, the purpose of the article is to study one of the manifestations of gender discrimination, namely the problem of gender equality in the sphere of labor. It involves the consistent solution to the following tasks: a) to emphasize the basic principles of gender international and legal policy; b) to reflect the praxeological dimension of providing the equal social and economic opportunities for men and women at current level; c) to emphasize the key criterion for ensuring the equality in socio-cultural sphere - equality in political life; d) to study the educational level of women and the possibility of self-realization in employment equal to men. Theoretical basis. The authors proceed from the standpoint that gender equality at the present stage has become a priority of legal policy and an important principle of the state (legal and democratic) of pro-European orientation. It is characterized in the legal plane, first of all, by the equality of the social roles of men and women, and the overcoming of the gender hierarchy of social ties, in which men are perceived as higher beings by their mental and physical abilities, and their activities are more significant and of priority in comparison with the activities of women. Originality. The authors have substantiated that in many economically developed countries the problem of providing a gender is still relevant, but most of the crisis problems in this area have found their legal regulation. The motivated position of the authors is that the level of education and professionalism of women cannot serve a reason for discrimination against women, which now exists in the economic and political sphere in the post-Soviet space. Conclusions. Gender stereotypes remain the priority in woman's keeping family household, which creates significant inequalities of women and men at the labor market. Specialized regulatory acts in the field of gender declare the equality of men and women, while labor law defines a number of norms and guarantees that complicate the employment of women. In order to improve the situation we propose to implement a number of measures, such as, creation and financial support of the programs at the state level for supporting maternity, family and childhood; examination of all normative acts and concerning the issue of gender asymmetry, and especially the norms of labor law; introduction of state monitoring of employment and income of persons as to the complying with the principle of gender equality; introduction of quotas for women's participation in political activities, in the work of the government and parliament, etc.

Keywords: gender; gender issues; gender identity; body; corporeality; man; woman; society; state; law; social philosophy; philosophy of law

\section{Introduction}

In present conditions of state-building and law-making processes, the philosophical approach to comprehension of social reality in general, and the legal reality in particular, is actualized. Such an approach is based on the modern dimension of civil society, in which there are no forms of discrimination, that involves solving a number of socially significant problems of the modern age, among which it is necessary to highlight the important problem of the XXI century, which is discrimination on the basis of gender. In fact, nowadays there is a shift in the pivotal emphasis of the philosophy of corporeality toward the rehabilitation of the body, underlying its significance for the epistemological identity of a human. For example, in the course of scientific research of contemporary social philosophy and philosophy of law, the interest in such terms as "public body", "psychology of body", "philosophy of body", etc., is more and more increasing. A very important theme of the philosophy of the present, that is the mutual influence of the body and power, which the philosophers have repeatedly written about in their treatises and works, 
speaking about the key meaning of corporeality for the struggle for the primacy of both socioreligious and state-political institutions, is not neglected either.

Speaking about the concept of gender, it is necessary to immediately point out two dimentions of its interpretation in scientific research, as a consequence of social and legal relations in which the activity is regulated by gender norms, and as determination of power relations in which an attempt to regulate the power of men and subjugation of women is most often carried out. In this case, the authors of the article adhere to the position according to which the gender socialization as a manifestation of the formation of sexual identity is an important component of social and legal socialization. Therefore, it is reasonable to state that the problem of gender in the context of contemporary development of society, state and law, is multidimensional by its nature and involves conducting research at the interdisciplinary level. Moreover, nowadays in the Ukrainian socio-cultural space it is still necessary to state the separation of society from the stereotype of belonging of such personal qualities as courage, professionalism, activity, autonomy in decisionmaking, determination and self-confidence, exclusively to men.

In general, the philosophical way of interpreting the difference between genders involves, first of all, their ontological dimension, without neglecting, of course, the physiological identity of a man and a woman. Philosophy also focuses on the pursuit of such a plane of understanding of gender corporeality, in which the individual and physiological features of a human being are normalized. For example, gender equality is one of the key principles of a civilized international community, which obliges all member states to define the principle of gender equality at the legislative level, but its declaration is not provided with proper socio-economic and political guarantees, and as a result the practical scope of the implementation of the principle is far from ideal.

In its turn, the discrimination issue is the topical aspect of human social coexistence. One of the discrimination manifestations is the issue of gender asymmetry. It should be noted that, in general, gender equality was formed into an essential principle of legal support, it is the criterion of relating the state to social, legal and democratic one. Nevertheless, gender equality of men and women in the practical aspect remains a very substantial social and legal issue which needs the scientific grounding. Moreover, the issue of gender equality and non-discrimination is extremely large-scale and needs a separate analysis within a separate application sphere.

Considering the special importance of the gender equality issue in the scholarly circles, it has found the reflection in different aspects of its manifestation. As to the researched criterion of the equality principle reflection in the sociocultural and philosophical and legal dimensions among the latest scientific works, a group of some scholars should be outlined. Thus, P.A. Frazier and J.C. Hunt, describing the ways of achieving the gender equality, stated the following: "by the ways in which gender and law interact, we assess the extent to which the law and human behavior solve the gender problem" (Frazier, \& Hunt, 1998, p. 1). Moreover, A. Masselot critically describing the recent legislative and policy initiatives in the field of gender equality in the European Union, stated that "the principle of gender equality should be applied in all areas of EU law as a fundamental right" (Masselot, 2007, p. 152). M. Szydło, researching the gender equality issue in three aspects: Economic Efficiency, Fundamental Rights and Democratic Legitimisation of Economic Governance, came to the conclusion that "there is a large gap between the proportion of employed and well-educated women and those sitting on the boards of EU companies, and this gap should be significantly diminished because it is mandated by the EU fundamental right to equality between women and men" (Szydło, 2015, p. 97). It is also worth mentioning P. Kapotases's scientific work on the gender quota in the Greek politics in accordance with EU Law, in which he states that "gender quotas in politics are left beyond the European legal norms, 
and the election post is not considered to be employment" (Kapotas, 2009, p. 29). R.-T. Ford, considering jurisprudence in the sphere of employment discrimination, assumes that key concepts such as "discrimination", "intent", "causation", and the other prohibited grounds of discrimination refer to discrete and objectively verifiable phenomena or facts (Ford, 2014, p. 1381).

However, the issues proposed for the solution in the article, within the post-Soviet and European states have not been the subject of a modern scientific analysis, which determines the scientific novelty and importance of this paper.

\section{Purpose}

Based on the comparative analysis of the post-Soviet countries, the purpose of the article is to study one of the manifestations of gender discrimination, namely the problem of gender equality in the sphere of labor. It involves the consistent solution to the following tasks: a) to emphasize the basic principles of gender international and legal policy; b) to reflect the praxeological dimension of providing the equal social and economic opportunities for men and women at current level; c) to emphasize the key criterion for ensuring the equality in socio-cultural sphere equality in political life; d) to study the educational level of women and the possibility of selfrealization in employment equal to men.

\section{Statement of basic materials}

Gender policy is the determination by the international bodies and states of the main gender priorities and basic fundamental values, principles and directions of activity, appropriate methods and ways of their implementation, aimed at the establishment of equal rights, freedoms, creating conditions and opportunities, guarantees of equal social, political and economic status of men and women, as well as the development of gender democracy and the formation of the gender culture in society (Shevchenko, 2016, p. 61).

The beginning of modern gender politics was laid in the General Declaration on Human Rights, which in Art. 2 prohibits certain differences in legal approaches under the set of discrimination factors, among which a person's gender is also determined. The same point of view is expressed in Art. 2 of the UN International Covenant on Economic, Social and Cultural Rights and the UN International Covenant on the Civil and Political Rights. The member states of such Covenants have an obligation to provide equal rights for men and women in taking advantage of all economic, social, cultural, civil and political rights.

However, the international community states the fact that, despite the existing general international ordinances, the status of women is still discriminative, and it violates the principle of equality and respect for human dignity. In 1979 the UN Convention on the Elimination of All Forms of Discrimination against women, was adopted, which for the first time paid special attention to such form of discrimination as gender equality.

Summing up this document let us determine its key legal meaning. The key role of the Convention is that it:

- determined the issue of "discrimination against women";

- elaborated the main directions of policy in the sphere of discrimination against women and established the mandatory inter-gender equality aspects;

- comprehensively defined the non-discrimination policy, through the creation of primary conditions in the member states, among which is the policy in the sphere of change of the so- 
cio-cultural stereotype behavior, improvement of the level of public legal culture in the aspect of gender equality;

- indicated the equality of rights of men and women not only in the private family relations, but also in all aspects of social life "in political, economic, social, cultural, public or any other sphere";

- at the regulatory level determined a complex of rights and freedoms to ensure the principles of equality between men and women.

Thus, gender equality at the modern stage has become a priority of legal politics and an essential principle of the legal state. In the legal area it is characterized first of all by the equality of the social roles of men and women, overcoming of the gender hierarchy of social connections, in which men are perceived in advance as superior with regards to their mental and physical capacities, and their activity is considered more important and is prioritized as compared to women's activity.

International and regional regulatory framework in the sphere of socio-economic gender equality can be divided into the following groups:

Regulatory acts counteracting the illegal trafficking of women and forced prostitution, such as the recommendations of the Parliamentary Assembly of the Council of Europe: Recommendation 1325 (1997) "On the illegal trafficking of women and forced prostitution in the European Council Member States"; Recommendation 1450 (2000) "On violence against women in Europe"; Recommendation 1545 (2002) "On campaign against illegal trafficking of women"; Recommendation 1610 (2003) "On migration connected with the illegal trafficking of women and prostitution"; Recommendation 1611 (2003) "On organs trafficking in Europe"; Recommendation 1663 (2004) "On home slavery: servants, "au pair" persons and purchased wives".

Regulatory acts on labor conditions and equal remuneration for labor, amongst which is the Social Charter (reviewed), Convention No. 100 of the International Organization "On equal remuneration for men and women for the labor of equal value" (1953), Directive of the Economic Community Council "On compliance with the equality of men and women in issues related to the work, professional education, career development, and labor conditions" (1976), Directive of the Economic Community Council "On constant compliance with the equality of men and women in issues related to social insurance" (1978), Convention of International Labor Organization No. 156 "On equal attitude and equal opportunities for the male and female employees: workers with the family liabilities" (1983), Directive of the Economic Community Council "On implementations of the principle of equality of men and women in the system of professional social insurance" (1986), etc.

Regulatory warranties of maternity and appropriate conditions of combining the birth of children and women's labor: Convention of the International Labor Oganization on maternity protection (reviewed in 1952) No. 103; Directive of the Economic Community Council "On the application of the principle of men and women equality in their activities, including agriculture, independent business activity, as well as the protection of women in employment, during the pregnancy and maternity period" (1986); Beijing Declaration (1995), Charter of the European Union on the fundamental rights (2000), Convention of International Labor Organization No. 89 on the night work of women in the industry (reviewed in 1948); Protocol 1990 to the Convention (reviewed) from 1948 on women's night work; Recommendation of International Labor Organization No. 13 concerning women's labor at night in the sphere of agriculture, 1921.

Despite the substantial attempts of the international organizations of different levels, the whole world community, as of now we still cannot state an appropriate or at least close to an appropriate insurance of equal socio-economic opportunities among men and women. 
National legislation of each separate state based on the general international standards determines the special legal norms, rights, liberties and warranties to provide for equal opportunities. Therefore, first of all let us conduct a comparative analysis of the regulatory basis of equality of rights according to the gender criteria. Obviously, in most economically developed countries the problem of gender equality remains topical, however, most critical issues in this direction have found their legal regulation. On the territory of the former post-Soviet states the discrimination according to the gender criteria is especially relevant. Therefore, the attention will be drawn to these territorial boundaries.

For the first demonstration of the issues of legal regulation of gender let us address the analytics which we unified into the Table 1.

Table 1

\section{Demonstration of issues in legal regulation of gender: the results of the analytical study}

\begin{tabular}{|c|c|c|}
\hline Country & $\begin{array}{l}\text { Presence of the consti- } \\
\text { tutional norm which } \\
\text { prohibits the discrimi- } \\
\text { nation according to the } \\
\text { gender identity }\end{array}$ & Specialized regulatory act \\
\hline Ukraine & $\begin{array}{l}\text { Art. } 24 \text { of the Ukrainian } \\
\text { Constitution }\end{array}$ & $\begin{array}{l}\text { Law "On the provision of equal rights and possi- } \\
\text { bilities for men and women" (2005) }\end{array}$ \\
\hline Russia & $\begin{array}{l}\text { Art. } 19 \text { of the Constitu- } \\
\text { tion of Russian Federa- } \\
\text { tion }\end{array}$ & $\begin{array}{l}\text { There is no special regulatory act, however, } \\
\text { starting from } 2003 \text { there is an intention to adopt } \\
\text { the draft Federal Law "On the state warranties of } \\
\text { equal rights and liberties of men and women and } \\
\text { equal abilities for their realization". }\end{array}$ \\
\hline Belarus & $\begin{array}{l}\text { Art. } 32,33 \text { of the Belo- } \\
\text { russian Constitution }\end{array}$ & $\begin{array}{l}\text { There is no special law; since } 2012 \text { the draft law } \\
\text { of the Republic of Belarus "On the Gender } \\
\text { Equality" has been discussed }\end{array}$ \\
\hline Kazakhstan & $\begin{array}{l}\text { Art. } 1 \text { of the Kazakh } \\
\text { Constitution }\end{array}$ & $\begin{array}{l}\text { The Law "On the state warranties of equal rights } \\
\text { and abilities for men and women" (2009) }\end{array}$ \\
\hline Azerbaijan & $\begin{array}{l}\text { Art. } 25 \text { of the Constitu- } \\
\text { tion of Azerbaijani Re- } \\
\text { public }\end{array}$ & $\begin{array}{l}\text { Law "On the Warranties of Equal Rights between } \\
\text { Men and Women" (2006) }\end{array}$ \\
\hline Uzbekistan & $\begin{array}{l}\text { Art. } 18 \text { of the Constitu- } \\
\text { tion of the Republic of } \\
\text { Uzbekistan }\end{array}$ & No special act \\
\hline Moldova & $\begin{array}{l}\text { Art. } 16 \text { of the Constitu- } \\
\text { tion of Moldova }\end{array}$ & $\begin{array}{l}\text { Law "On the insurance of equal possibilities for } \\
\text { men and women" (2006) }\end{array}$ \\
\hline Georgia & $\begin{array}{l}\text { Art. } 14 \text { of the Constitu- } \\
\text { tion of Georgia }\end{array}$ & Law on Gender Equality (2010) \\
\hline Armenia & $\begin{array}{l}\text { Art. } 15 \text { of the Constitu- } \\
\text { tion of Armenia }\end{array}$ & $\begin{array}{l}\text { On equal rights and equal possibilities for men } \\
\text { and women (2013) }\end{array}$ \\
\hline
\end{tabular}


Adoption of the constitutions of independent states for the first time activated the issues of gender equality. In contrast to the post-Soviet states, the states with a stable constitutional formation solved this problem at least half a century ago. Thus, in Germany, gender equality was fixed as a principle already in the Constitution of 1949 (article 3, chapter 2 and chapter 3, suggestion 1). Positive is the fact that all the countries being analyzed, have determined gender equality in their Constitutions as a key principle of functioning of the state and legal phenomena. Still some constitutional norms are formulated incorrectly. For instance, Art. 32 of the Constitution of the Republic of Belarus states: "Women are granted the same possibilities as men in obtaining education and professional training, in the work and career development, in the socio-political, cultural and other spheres of activity, as well as the creation of conditions for their labor safety and healthcare". The above mentioned vividly demonstrates the gender asymmetry, where the men are perceived as a certain positive standard, and women, as the persons who should achieve this standard.

The gap is not only in the constitutional declaration, but also in the specialized normative regulation. While the specialized acts about the equality of men and women were passed in Great Britain, Lithuania, Netherlands, Norway, Finland, France, Sweden and Japan in the 90s of the previous century, the situation is totally different in the post-Soviet area. Generally, the post-Soviet countries fall 15-20 years behind with regard to passing the regulatory act on gender equality. The crisis is also determined by the fact that several countries with vast territories and large population have not passed such an act at all (Russia, Belarus, Uzbekistan). Moreover, the scholarly community of such countries is at a stage of discussion about the necessity of passing such an act.

Analysis of the social life and social practices testifies to the fact that the society, which is still influenced by the Soviet system of the social and legal relations, often has a declarative nature of their legal norms. Moreover, this issue is manifested not only in the current topic, but also in other spheres of life. The key problem of the laws of post-Soviet countries in the sphere of gender equality is the declarative nature of its provisions.

The politics in the researched countries has always been considered a male issue. The level of civil society development has not achieved the conditions to provide for the appropriate political activity of women as of now. Concerning the political participation aspects as: 1) the right to vote and 2) the right to be elected, there is a certain imbalance. While there are no problems with the first criterion, as the Soviet system and its legal successors generally warranted and provided for the voting equality, the issue of women's active political activity remains outside the practical application till this day. The key factor, which hinders an efficient implementation of gender equality, remains the domination of the social stereotypes of predominantly patriarchal type of administration.

Analytically, we determined the women's coefficient in the operating national leadership. For instance, we selected Ukraine, as it was the first out of the post-Soviet states to adopt a specialized law on gender equality. The results of the authors' research have been unified into Table 2 (analytics as of May 20, 2018). 


\section{The ratio of women in the current national leadership (Ukraine): the results of the analytical study}

\begin{tabular}{|c|c|c|c|}
\hline Name of the state Governmental Agency & $\begin{array}{l}\text { General mem- } \\
\text { bership of the } \\
\text { governing } \\
\text { authority }\end{array}$ & $\begin{array}{l}\text { Number of wom- } \\
\text { en in the gover- } \\
\text { ning agency }\end{array}$ & \begin{tabular}{|l|}
$\begin{array}{l}\text { Percent } \\
\text { (rounded to } \\
\text { the whole) }\end{array}$ \\
\end{tabular} \\
\hline Cabinet of Ministers of Ukraine & 24 & 3 & 12 \\
\hline $\begin{array}{l}\text { Ministry of Agrarian Policy and Food of } \\
\text { Ukraine }\end{array}$ & 6 & 2 & 33 \\
\hline $\begin{array}{l}\text { Ministry of Regional Development, Building } \\
\text { and Housing and Communal Services }\end{array}$ & 6 & 0 & 0 \\
\hline $\begin{array}{l}\text { Ministry of Environment and Mineral Re- } \\
\text { sources of Ukraine }\end{array}$ & 5 & 0 & 0 \\
\hline $\begin{array}{l}\text { Ministry of Temporarily Occupied Territories } \\
\text { and Internally Displaced Persons }\end{array}$ & 5 & 0 & 0 \\
\hline Ministry of Internal Affairs of Ukraine & 5 & 1 & 20 \\
\hline Ministry of Foreign Affairs of Ukraine & 5 & 1 & 20 \\
\hline Ministry of Information Policy of Ukraine & 4 & 1 & 25 \\
\hline Ministry of Culture of Ukraine & 5 & 2 & 40 \\
\hline Ministry of Infrastructure of Ukraine & 5 & 0 & 0 \\
\hline Ministry of Youth and Sports of Ukraine & 7 & 0 & 0 \\
\hline Ministry of Defence of Ukraine & 7 & 0 & 0 \\
\hline Ministry of Healthcare & 5 & 2 & 40 \\
\hline Ministry of Social Policy of Ukraine & 5 & 2 & 40 \\
\hline Ministry of Justice of Ukraine & 8 & 1 & 12 \\
\hline Prosecutor General's Office of Ukraine & 7 & 1 & 14 \\
\hline Security Service of Ukraine & 7 & 0 & 0 \\
\hline The Constitutional Court of Ukraine & 16 & 1 & 6 \\
\hline Regional State Administrations & 27 & 0 & 0 \\
\hline
\end{tabular}

The analysis proves that in eight ministries and governing state agencies there are no women in senior management at all. Besides, the general state approach to the problem is really disturbing. The spheres of education and healthcare are the only ones, which remain dominated by women. Generally, the percentage of women in the managerial personnel of superior and central state power of Ukraine constitutes to only $6 \%$. This demonstrates that for 13 years since the adoption of corresponding specialized acts the issue still has not found any progressive solutions.

In order to prove the representativeness of the Ukrainians' experience, let us address this particular problem in other countries. This time for the sample group we took government representatives. For instance, in Russia, out of 32 of the total members of government, there are 3 women. Such countries as Belarus (31 members of government), Turkmenistan (33), Armenia (22) are unified by the fact that there is only one woman in their acting government. In European countries such an index is much higher. In Bulgaria the governmental membership of men and women is equal (12 persons each), in Canada - 9 women, in Denmark - 8, in Germany - 7, and in Sweden - 13 (Central Intelligence Agency, 2017). 
The parliament does not show any other indexes. Amongst 450 people's deputies of Ukraine there are 51 women in the acting parliament. Most of them were admitted by quotas from fractions, parties and blocks. Only two women were admitted to the parliament under the majority voting system. We think that the reasons why women cannot appropriately compete with men in the political sphere are as follows: the limitation of women's sphere of activity by the household matters and family; limited biological time for a woman's political career, especially in the aspect of its combination with maternity; insufficient financial support; absence of the state traditions of women's leadership. The mentioned above reconfirms the unreadiness of the post-Soviet society for the change of traditional state and political values and traditions.

Therefore, the introduction of quotas to the elective positions is a particularly international practice. Unfortunately, no legislative act concerning the election laws contains a distinct indication to the quotas, the legislation is only a type of recommendation. In Art. 15 of the Law "On insurance of equal rights and possibilities for men and women" there is a statutory reference which determines that "political parties, electoral blocks during the nomination of people's deputies of Ukraine in the multi-mandate electoral constituency provide for the representation of women and men in the corresponding electoral lists" (Verkhovna Rada of Ukraine, 2005). Such a formulation of the legal norm is not very distinct, as it does not indicate the specific percentage quota, besides, there is no liability of the subject in case of non-fulfillment of such an ordinance. Therefore, in the acting Ukrainian parliament two fractions do not have any women at all.

Generally, the educational level of the younger generation of women is higher than that of men. The European index proves that the percentage of women aged 30-34, who obtained higher education, exceeds the level of men by $9.5 \%$ (Eurostat Statistic Explaind, 2018). The postSoviet countries preserve such a tendency, that, for instance, in Moldova the level of young men's education is $6.9 \%$ lower than the women's (Eurostat Statistic Explaind, 2017), and in Armenia it is $5.9 \%$.

The gender equality principle in the area of work remuneration is especially obvious in the post-Soviet states. The level of the women's education is higher than the men's, however women are paid practically three times less than men. This fact could be explained by different production and industrial areas of employment, if statistics didn't prove otherwise. In such areas as financial and insurance activities, where the primary possibilities do not depend on gender - the level of women's salary amounts to $68 \%$ from the income of men at the equal loading (according to the data of Ukrainian Statistics 16.5 ths. UAH for men and 11.2 ths. UAH for women (State Statistics of Ukraine, 2017)). Such a tendency is characteristic of most post-Soviet countries. Specialists with the higher qualification level in Russia for 2017 (State Statistics of Ukraine, 2017) men $-6,449$, and women - 11,104. It means that the correlation is approximately $58 \%$. Moreover, men's salary is $72 \%$ higher than the women's.

The possibilities in the sphere of women's employment first of all are corrected by the unemployment level in Ukraine. Thus, according to the statistical data the unemployment level in 2017 in the European Union Countries amounted to $7.7 \%$ (The Statistics Portal, 2017). In Ukraine this index reaches $9.9 \%$ (State Statistics of Ukraine, 2017).

In our point of view, the following categories of women inequality at the labor market should be singled out.

Absence of career development possibilities. The reasons for such inequality are constituted first of all by the fact that the post-Soviet society is not ready to provide equal possibilities of career development for men and women. Management positions, not only in politics, as it has already been shown earlier, but also in other areas, are occupied by men. Even in the area of edu- 
cation, which has always been women's qualification in these countries. Modern national researches testify to the essential feminization in the area (women's representation constitutes about $78.3 \%$ ), however, the amount of men and women differs at different stages of education hierarchy and at different levels of education. While the pre-school educational institutions are represented predominantly by women $(98.6 \%)$, in the teaching staff of higher educational institutions practically half of the teachers is represented by men. Women occupy the ordinary positions of teachers, lecturers and kindergarten teachers, however, the headmasters of secondary schools are represented by men almost by $40 \%$, and the rectors of the higher educational institutions by $90 \%$ ("Strategy of gender equality in the sphere of education", 2017). There is a sociallypsychological stereotype - a man is always a good manager and administrator. Statistics, however, show the opposite. Researches prove that companies with a greater share of women in the managerial staff are more successful: they are $10 \%$ more profitable with regard to the equity capital and show $48 \%$ higher operating result and $70 \%$ higher growth of the shares value. The presence of at least one woman in the board of directors reduces the risks of bankruptcy by full $20 \%$ (Clapon, 2017).

Gender-stereotyped values in the manegial field deforms the idea of a real picture of the functioning of an enterprise or institution, leads to incorrect management solutions and generally impacts the development of the economy and the state.

The shortcomings of the labor law. In the researched states the norms of the labor Soviet law have been preserved. For instance, in Ukraine there is a Code of Laws on Labor from 1971 where most of norms do not comply with the modern conditions of the labor market development in a competitive environment. The law contains a set of norms, which, are, supposedly, aimed at the warranty of women's labor, protection of maternity and family. However, according to statistics, they, in fact, hinder the employment of women and their competition at the labor market. For example, Art. 175 of the Code of Labor Laws prohibits using women's labor at tough works and works with the dangerous or harmful working conditions, as well as underground work; restricts women's work at night hours; Art. 176 prohibits the involvement of women, who have children under the age of three, in work at night hours, overtime work, at weekends, and business trips. Such norms facilitate the employers in avoiding the employment of women, especially young women of childbearing age and those with young children. Similar norms are contained in Art. 253 and Art. 259 of the Labor Code of the Russian Federation (State Duma of the Russian Federation, 2001), Art. 248 and Art. 249 of the Labor Code of the Republic of Moldova (Parliament of the Republic of Moldova, 2003).

The asymmetry of employment by different industries. There is a clear boundary between men's and women's professions in the post-Soviet countries. For instance, the correlation of the graduates in the area of science and engineering in Belarus is 43 ths. men against 17 ths. women (Eurostat Statistic Explaind, 2018). The European Union states also demonstrate a gap, however, here it constitutes to $13 \%$ on average.

The absence of a family and household gender parity. The stereotype, according to which the household work belongs to the woman, and on average, a woman works practically 4-6 hours more than a man, is that the household work is not considered as productive (Zbarzhevetska, \& Samsonova, 2010, p. 256). Accordingly, the woman is not physically able and is limited in time for the same implementation as men. The child's upbringing and household work is not distributed within the couple evenly till now. The policy of balancing between work and family duties may at the same time reinforce gender inequality in terms of the division of labor in households and undermine gender equality in the area of employment. 
The Family Law acknowledges the equality of spouses, however, in the possibility of a divorce, in most cases the courts tend to leave the children with mothers, thus actually establishing their liability of upbringing. Only in 2018 the public register of debtors with alimony debts began to operate in Ukraine (Ministry of Justice of Ukraine, 2018), and it contains more than 75 thousand of electronic records.

The problem of employment inequality is complex. In the post-Soviet area there is a substantial problem in the field of actual warranty of children's upbringing. The level of coverage of children by pre-school educational institutions amounts to $57 \%$, which is conditioned predominantly by the lack of appropriate infrastructure, and the lack of places in the kindergartens (State Statistics Service of Ukraine, 2018). Predominantly, women shall stay at home to bring the children up, or agree to the minimum salary, partial employment, to receive work with flexible working hours.

Besides, the state does not provide for the possibility of qualification improvement, knowledge update for women who left their maternity leave. After giving birth to two children a woman, on average, falls behind with regard to the qualification level by 6 years, therefore, the knowledge and skills update is an essential element to ensure equal possibilities. No warranties, priviliges or indications are provided for by the acting norms of law. Also the mentioned period of time essentially affects women's time in employment, and, correspondingly, their pension coverage. The child-care systems funded at the expense of the state, open possibilities for harmonization of the issues of combining work and family responsibilities with the aspects of gender equality. Under the conditions that child care is provided, men and women may compete at the labor market under equal conditions. There is an appropriate solution to this issue. Thus, in many states the quotas for women are provided at the publicly quoted companies, among which are Norway (2003), Spain (2007), Iceland and France (2010), Belgium and Italy (2011), the Netherlands (2012), Denmark (2013) and Germany (2014). As a result, the amount of countries with gender quotas at the publicly quoted companies, or at the state companies increased four times.

\section{Originality}

It has been grounded in the article that in many economically developed countries, the issue of providing a gender is still relevant, but most of the crisis problems in this area have found their legal regulation. The motivated position of the authors is that the level of education and professionalism cannot be the reason for the significant discrimination against women, which now exists in the field of employment in the post-Soviet area.

\section{Conclusions}

The post-Soviet countries, despite certain steps in the area of insurance of the gender equality principle traditionally remain on a primary level of discrimination. With the equal educational qualification the payment for the women's work and their demand at the labor market is much lower. Gender stereotypes remain the priority in woman's keeping family household, which creates significant inequalities of women at the labor market. Specialized regulatory acts in the field of gender declare the equality of men and women, while labor law defines a number of norms and guarantees that complicate the employment of women.

In order to improve the situation we propose to implement a number of measures:

- introduction of educational and cultural programs concerning the cultivation of the gender parity psychology for the young generation; 
- creation and financial support of the programs at the state level for supporting maternity, family and childhood;

- examination of all normative acts and by-laws concerning the issue of gender asymmetry, and especially the norms of labor law;

- introduction of state monitoring of employment and income of persons as to the complying with the principle of gender equality;

- introduction of quotas for women's participation in political activities, in the work of the government and parliament;

- equalization of the labor payment between the industries and reduction of differences in the content and payment of labor according to gender identity;

- creation and introduction of programs facilitating the development of women's small and medium business;

- creation of conditions as to the life-time studying, which, correspondingly, is connected with the necessity of adaptation to the requirements of the globalized society.

\section{REFERENCES}

Chiefs of state and Cabinet Members of foreign governments. (2017). Central Intelligence agency. Retrieved from https://www.cia.gov/library/publications/world-leaders-1/ (in English)

Clapon, P. (2017). Here's why you should encourage gender equality in your company. The HR and Employee Engagement Community. Retrieved from https://gethppy.com/hrtrends/heres-why-you-should-encouragegender-equality-in-your-company (in English)

Doshkilni navchalni zaklady. (2018). State Statistics Service of Ukraine. Retrieved from http://www.ukrstat.gov.ua/ (in Ukrainian)

European neighborhood policy - East - education statistics. (2017). Eurostat Statistic Explaind. Retrieved from https://ec.europa.eu/eurostat/statistics-explained/index.php/European_Neighbourhood_Policy_-_East_-_ education_statistics (in English)

File: Number of tertiary graduates in science and technology relative to the size of the population aged 20-29 years, 2016 (per 1000 male female inhabitants aged 20-29) ENPE17.png. (2018). Eurostat Statistic Explaind. Retrieved from http://ec.europa.eu/eurostat/statistics-explained/index.php?title=File:Number_of_tertiary_ graduates_in_science_and_technology_relative_to_the_size_of_the_population_aged_20-29_years,_2016_ (per_1_000_male_female_inhabitants_aged_20-29)_ENPE17.png (in English)

Ford, R. T. (2014). Bias in the air: Rethinking employment discrimination law. Stanford Law Review, 66, 13811421. Retrieved from http://www.stanfordlawreview.org/wp-content/uploads/sites/3/2014/06/66_Stan_ L_Rev_1381_Ford.pdf (in English)

Frazier, P., \& Hunt, J. (1998). Research on gender and the law: Where are we going, where have we been? Law and Human Behavior, 22(1), 1-16. doi: 10.1023/A:1025774920650 (in English)

Gender statistic. (2018). Eurostat Statistic Explaind. Retrieved from http://ec.europa.eu/eurostat/statisticsexplained/index.php?title=Gender_statistics\#Gender_overall_earnings_gap (in English)

Kapotas, P. (2010). Gender quotas in politics: The greek system in the light of EU law. European Law Journal, 16(1), 29-46. doi: 10.1080/00344893.2013.850322 (in English)

Masselot, A. (2007). The State of gender equality Law in the European Union. European Law Journal, 13(2), 152168. doi: 10.1111/j.1468-0386.2007.00361.x (in English)

Serednomisiachna zarobitna plata zhinok ta cholovikiv za vydamy ekonomichnoi diialnosti u 2017 rotsi. (2017). State Statistics of Ukraine. Retrieved from http://www.ukrstat.gov.ua/operativ/operativ2017/gdn/Szp_ ed/Szp_ed_u/Szp_ed_2017_u.htm (in Ukrainian)

Shevchenko, Z. (2016). Slovnyk gendernykh terminiv. Cherkasy: Chabanenko Y. (in Ukrainian)

Stratehiia uprovadzhennia hendernoi rivnosti ta nedyskryminatsii u sferi osvity "Osvita: hendernyi vymir - 2020". (2017). Simia pid Pokrovom Bohorodytsi. Retrieved from https://gloria.tv/album/ LgSk1KGcWD4y1zmFwPJ6ZNZgH/record/dtWBre3YkaK81oyAZGwb4eNwy (in Ukrainian) 
Szydło, M. (2015). Gender equality on the boards of EU companies: Between economic efficiency, fundamental rights and democratic legitimisation of economic governance. European Law Journal, 21(1), 97-115. doi: 10.1111/eulj.12074 (in English)

Trudovoy kodeks Respubliki Moldova 28.03.2003 N 154-XV, № 648. (2003). Retrieved from http://lex.justice.md/ $\mathrm{ru} / 326757 /$ (in Russian)

Trudovoy kodeks Rossiyskoy Federatsii 30.12.2001 N 197-FZ. (2001). Retrieved from http://www.consultant.ru/ document/cons_doc_law_34683/(in Russian)

Unemployment rate in the European Union and the Euro area from 2007 to 2017. (2017). The statistics Portal. Retrieved from https://www.statista.com/statistics/267906/unemployment-rate-in-eu-and-euro-area/ (in English)

Vidomosti Verkhovnoji Rady Ukrainy, 2005, 52, ст. 561: Zakon Ukrainy 2005, № 2866-IV. (2005). Retrieved from http://zakon3.rada.gov.ua/laws/show/2866-15 (in Ukrainian)

Yedynyi reiestr borzhnykiv. (2018). Ministry of Justice of Ukraine. Retrieved from https://erb.minjust.gov.ua/ (in Ukrainian)

Zbarzhevetska, L. D., \& Samsonova, K. V. (2010). Of gender inequality in the workplace. The Collection of Scientific Works of Kirovohrad National Technical University. Economic Sciences, 18(1), 255-262. Retrieved from http://nbuv.gov.ua/UJRN/Npkntu_e_2010_18(1)_44 (in Ukrainian)

\section{LIST OF REFERENCE LINKS}

Chiefs of State and Cabinet Members of Foreign Governments [Virtual Resource] // Central Intelligence agency. 2017. - Access Mode: https://www.cia.gov/library/publications/world-leaders-1/ - Title from Screen. Date of Access: 13.04.2019.

Clapon, P. Here's why you should encourage gender equality in your company [Virtual Resource] / P. Clapon // The HR and Employee Engagement Community. - 2017. - Access Mode: https://gethppy.com/hrtrends/hereswhy-you-should-encourage-gender-equality-in-your-company - Title from Screen. - Date of Access: 13.04.2019.

Дошкільні навчальні заклади [Електронний ресурс] / Державна служба статистики України. - 2018. - Режим доступу: http://www.ukrstat.gov.ua/ (дата звернення 13.04.2019). - Назва з екрану.

European Neighborhood Policy - East - education statistics [Virtual Resource] // Eurostat Statistic Explaind. - 2017. Access Mode: https://ec.europa.eu/eurostat/statistics-explained/index.php/European_Neighbourhood_ Policy_-_East_-_education_statistics - Title from Screen. - Date of Access: 13.04.2019.

File: Number of tertiary graduates in science and technology relative to the size of the population aged 20-29 years, 2016 (per 1000 male female inhabitants aged 20-29) ENPE17.png [Virtual Resource] // Eurostat Statistic Explaind. - 2018. - 16 January. - Access Mode: http://ec.europa.eu/eurostat/statistics-explained/index.php? title=File:Number_of_tertiary_graduates_in_science_and_technology_relative_to_the_size_of_the_populatio n_aged_20-29_years,_2016_(per_1_000_male_female_inhabitants_aged_20-29)_ENPE17.png - Title from Screen. - Date of Access: 13.04.2019.

Ford, R. T. Bias in the Air: Rethinking Employment Discrimination Law [Virtual Resource] / R. T. Ford // Stanford Law Review. - 2014. - Vol. 66. - P. 1381-1421. Access Mode: http://www.stanfordlawreview.org/wpcontent/uploads/sites/3/2014/06/66_Stan_L_Rev_1381_Ford.pdf - Title from Screen. - Date of Access: 13.04.2019.

Frazier, P. A. Research on Gender and the Law: Where Are We Going, Where Have We Been? / P. A. Frazier, J. S. Hunt // Law and Human Behavior. - 1998. - Vol. 22, Iss. 1. - P. 1-16. doi: 10.1023/A:1025774920650

Gender statistic [Virtual Resource] / Eurostat Statistic Explaind. - 2018. - Access Mode: http://ec.europa.eu/ eurostat/statistics-explained/index.php?title=Gender_statistics\#Gender_overall_earnings_gap - Title from Screen. - Date of Access: 13.04.2019.

Kapotas, P. Gender Quotas in Politics: The Greek System in the Light of EU Law / P. Kapotas // European Law Journal. - 2010. - Vol. 16, № 1. - P. 29-46. doi: 10.1080/00344893.2013.850322

Masselot, A. The State of Gender Equality Law in the European Union / A. Masselot // European Law Journal. 2007. - Vol. 13, № 2. - P. 152-168. doi: 10.1111/j.1468-0386.2007.00361.x

Середньомісячна заробітна плата жінок та чоловіків за видами економічної діяльності у 2017 році [Електронний ресурс] // Державна служба статистики України. - 2017. - Режим доступу: http://www.ukrstat. gov.ua/operativ/operativ2017/gdn/Szp_ed/Szp_ed_u/Szp_ed_2017_u.htm (дата звернення 13.04.2019). Назва з екрану.

Словник гендерних термінів / укл. 3. В. Шевченко. - Черкаси : Чабаненко Ю., 2016. - 336 с. 
Стратегія упровадження гендерної рівності та недискримінації у сфері освіти "Освіта: гендерний вимір 2020" [Електронний ресурс] / Сім'я під Покровом Богородиці. - 2017. - 26 березня. - Режим доступу: https://gloria.tv/album/LgSk1KGcWD4y1zmFwPJ6ZNZgH/record/dtWBre3YkaK81oyAZGwb4eNwy (дата звернення 13.04.2019). - Назва з екрану.

Szydło, M. Gender Equality on the Boards of EU Companies: Between Economic Efficiency, Fundamental Rights and Democratic Legitimisation of Economic Governance / M. Szydło // European Law Journal. - 2015. Vol. 21, Iss. 1. - P. 97-115. doi: 10.1111/eulj.12074

Трудовой кодекс Республіки Молдова [Электронный ресурс] / Парламент республіки Молдова : [принятый от 28.03.2003, № 154-XV статья № 648 с изменениями]. - Кишинэу, 2003. - Режим доступа: http://lex.justice.md/ru/326757/ (дата звернення 13.04.2019). - Назва з екрану.

Трудовой кодекс Российской Федерации [Электронный ресурс] // Государственная Дума Российской Федерации : [принятый от 30.12.2001, № 197-Ф3 : отвечает офиц. тексту : на 1.04.2019]. - Москва, 2001. Режим доступа: http://www.consultant.ru/document/cons_doc_law_34683/ (дата звернення 13.04.2019). Назва з екрану.

Unemployment rate in the European Union and the Euro area from 2007 to 2017 [Virtual Resource] // The statistics Portal. - 2017. - Access Mode: https://www.statista.com/statistics/267906/unemployment-rate-in-eu-andeuro-area/ - Title from Screen. - Date of Access: 13.04.2019.

Про забезпечення рівних прав та можливостей жінок і чоловіків [Електронний ресурс] // Відомості Верховної Ради України 2005, № 52, ст. 561 : Закон України : [прийнятий Верховною Радою України 08.09.2005, № 2866-IV із змінами : відповідає офіц. тексту]. - Київ, 2005. - Режим доступу: https://zakon.rada.gov.ua/laws/show/2866-15 (дата звернення 13.04.2019). - Назва з екрану.

Єдиний реєстр боржників [Електронний ресурс] // Міністерство юстиції України. - Режим доступу: https://erb.minjust.gov.ua/ (дата звернення 13.04.2019). - Назва з екрану.

Збаржевецька, Л. Д. Гендерна рівність у сфері праці / Л. Д. Збаржевецька, К. В. Самсонова // Наукові праці Кіровоградського національного технічного університету. Економічні науки. - 2010. - Вип. 18, Ч. 1. C. 255-262. - Режим доступу: http://nbuv.gov.ua/UJRN/Npkntu_e_2010_18(1)_43 (дата звернення 13.04.2019). - Назва з екрану.

\author{
В. С. БЛІХАР ${ }^{1 *}$, І. М. ЖАРОВСЬКА ${ }^{2 *}$ І. О. ЛИЧЕНКО ${ }^{3 *}$ \\ 1*Львівський державний університет внутрішніх справ (Львів, Україна), ел. пошта blikharv@ukr.net, \\ ORCID 0000-0001-7545-9009 \\ 2* Національний університет "Львівська політехніка" (Львів, Україна), ел. пошта irazhar@ukr.net, \\ ORCID 0000-0003-3821-8120 \\ 3*Національний університет "Львівська політехніка" (Львів, Україна), ел. пошта lychenko7@gmail.com, \\ ORCID 0000-0002-4838-3579
}

\title{
СОЦІОКУЛЬТУРНИЙ І ФІЛОСОФСЬКО-ПРАВОВИЙ ВИМІРИ ПРОБЛЕМИ ГЕНДЕРНОЇ УДЕНТИЧНОСТІ
}

Мета. Метою статті є дослідження на основі компаративістського аналізу законодавства країн європейського та пострадянського простору одного з проявів гендерної дискримінації, а саме: гендерної нерівності у сфері праці. Це передбачає послідовне розв'язання таких задач: а) акцентувати, якими саме засадничими нормами регламентується гендерна міжнародно-правова політика; б) відобразити праксеологічний вимір забезпечення рівних соціально-економічних можливостей для чоловіків та жінок на сучасному рівні; в) наголосити на ключовому критерії забезпечення рівності в соціокультурній сфері - рівності в політичному житті; г) вивчити освітній рівень жінок та можливість рівної з чоловіками самореалізації у сфері зайнятості. Теоретичний базис. Автори виходять із позиції, що гендерна рівність на сучасному етапі стала пріоритетом правової політики і вагомим принципом (правової, демократичної) держави проєвропейської орієнтації. Ця політика у правовій площині характеризується передусім рівністю соціальних ролей чоловіків і жінок, подоланням гендерної ієрархічності соціальних зв'язків, у яких чоловіки зазнаки сприймаються як вищі за розумовими та фізичними здібностями істоти, їхня діяльність $є$ найбільш значущою та пріоритетною порівняно з діяльністю жінок. Наукова новизна. Авторами обгрунтовано, що у багатьох економічно розвинутих країнах проблема забезпечення гендера хоча й залишається актуальною, однак більшість кризових проблем 
у цьому напрямі знайшли своє правове регулювання. Мотивованою позицією авторів є те, що рівень освіченості, фаховості жінок не може слугувати причиною для дискримінації жінок, що нині існує в економічній та політичній сфері на пострадянському просторі. Висновки. Гендерні стереотипи залишають пріоритет жінки у веденні сімейного та побутового домогосподарства, що створює значну нерівність жінок і чоловіків на ринку праці. Спеціалізовані нормативні акти у сфері гендера декларують рівність статей, при цьому трудове законодавство визначає ряд норм та гарантій, які ускладнюють працевлаштування жінок. Для покращення ситуації пропонується втілити низку заходів, у числі яких: створення та матеріальне забезпечення на державному рівні програм щодо підтримки материнства, сім’ї та дитинства; експертиза всіх нормативних та підзаконних актів щодо питання гендерної асиметрії, особливо норм трудового права; запровадження державного моніторингу стану працевлаштування та оплати праці осіб щодо дотримання принципу гендерної рівності; уведення квот на участь жінок у політичній діяльності, у роботі уряду та парламенту тощо.

Ключові слова: ґендер; гендерні проблеми; гендерна ідентичність; тіло; тілесність; чоловік; жінка; суспільство; держава; право; соціальна філософія; філософія права

\author{
В. С. БЛИХАР ${ }^{1 *}$, И. М. ЖАРОВСКАЯ ${ }^{2 *}$, И. А. ЛЫЧЕНКО ${ }^{3 *}$ \\ 1* Львовский государственный университет внутренних дел (Львов, Украина), эл. почта blikharv@ukr.net, \\ ORCID 0000-0001-7545-9009 \\ ${ }^{2 *}$ Национальный университет "Львовская политехника" (Львов, Украина), эл. почта irazhar@ukr.net, \\ ORCID 0000-0003-3821-8120 \\ 3*Национальный университет "Львовская политехника" (Львов, Украина), эл. почта lychenko7@gmail.com, \\ ORCID 0000-0002-4838-3579
}

\title{
СОЦИОКУЛЬТУРНЫЙ И ФИЛОСОФСКО-ПРАВОВОЙ АСПЕКТЫ ПРОБЛЕМЫ ГЕНДЕРНОЙ ИДЕНТИЧНОСТИ
}

Цель. Целью предлагаемой статьи является исследование на основе компаративистского анализа законодательства стран европейского и постсоветского пространства одного из проявлений гендерной дискриминации, а именно: гендерного неравенства в сфере труда. Поставленная цель предусматривает разрешение следующих задач: а) акцентировать, какими именно фундаментальными нормами регламентируется гендерная международно-правовая политика; б) осветить праксиологический аспект обеспечения равных социальноэкономических возможностей для мужчин и женщин на современном уровне; в) акцентировать на ключевом критерии обеспечения равенства в социокультурной сфере - равенстве в политической жизни; г) изучить образовательный уровень женщин и возможности равной с мужчинами самореализации в сфере занятости. Теоретический базис. Авторы исходят из того, что гендерное равенство на современном этапе стало приоритетом правовой политики и весомым принципом правового, демократического государства проевропейской ориентации. Эта политика в правовой плоскости характеризуется прежде всего равенством социальных ролей мужчин и женщин, преодолением гендерной иерархичности социальных связей, в которых мужчины заведомо воспринимаются как высшие по интеллектуальным и физическим способностям существа, их деятельность является наиболее значимой и приоритетной по сравнению с деятельностью женщин. Научная новизна. Авторами обосновывается, что во многих экономически развитых странах проблема обеспечения гендера хотя и остается актуальной, однако большая часть кризисных проблем в данном направлении нашли свое правовое регулирование. Мотивированная позиция авторов состоит в том, что уровень образованности, профессионализма женщин не может служить причиной их дискриминации, характерной для экономической и политической сфер на постсоветском пространстве. Выводы. Гендерные стереотипы оставляют приоритет женщин в ведении семейного и бытового домохозяйства, что порождает значительное неравенство женщин и мужчин на рынке труда. Специализированные нормативные акты в сфере гендера декларируют равенство полов, при этом трудовое законодательство содержит ряд норм и гарантий, усложняющих трудоустройство женщин. Для улучшения ситуации предлагается предпринять ряд мер, в числе которых создание и материальное обеспечение на государственном уровне программ по поддержке материнства, семьи и детства; экспертиза всех нормативных и подзаконных актов в вопросе гендерной асимметрии, особенно норм трудового права; государственный мониторинг состояния трудоустройства и оплаты труда лиц в отношении соблюдения принципа гендерного равенства; введение квот на участие женщин в политической деятельности, в работе правительства и парламента и т.д. 
Ключевые слова: гендер; гендерные проблемы; гендерная идентичность; тело; телесность; мужчина; женщина; общество; государство; право; социальная философия; философия права

Received: 15.12 .2018

Accepted: 20.03.2019 